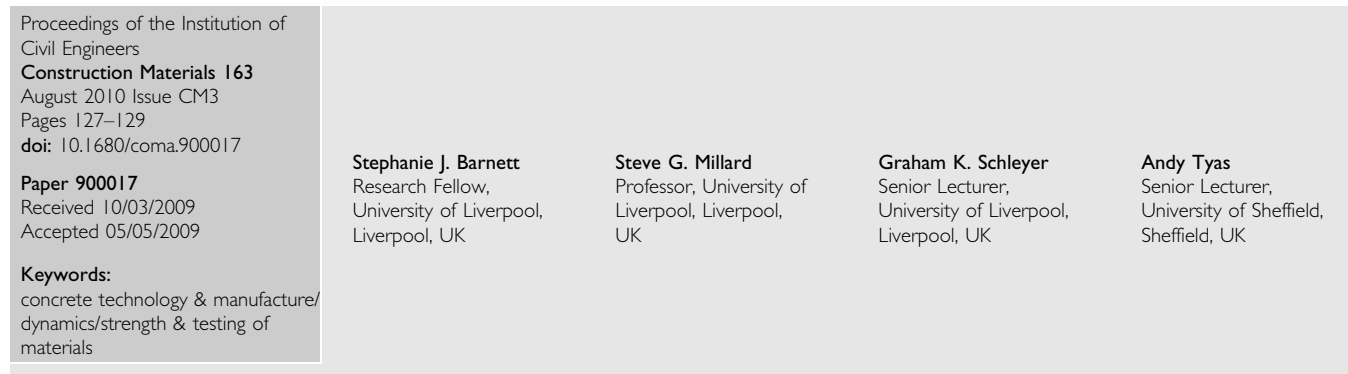

\title{
Briefing: Blast tests of fibre-reinforced concrete panels
}

S. J. Barnett PhD, MlnstP, CPhys, S. G. Millard PhD, CEng, MICE, G. K. Schleyer PhD, CEng, MIMechE, A. Tyas PhD

This briefing paper describes explosion testing of ultrahigh-performance, fibre-reinforced concrete panels. Four panels measuring $3.5 \mathrm{~m} \times 1.3 \mathrm{~m} \times 100 \mathrm{~mm}$ were subjected to $100 \mathrm{~kg}$ trinitrotoluene-equivalent explosion loading. Variables included type and quantity of fibre reinforcement, the use of conventional steel reinforcing bars and the stand-off distance of the panels from the explosive charge. The panels were found to resist explosion loading without creating shrapnel. Panels without secondary steel reinforcement were severely cracked but remained standing after testing at a stand-off distance of $12 \mathrm{~m}$. Panels with steel reinforcing bars withstood the explosion at closer stand-offs (down to $7 \mathrm{~m}$ ) with only minor cracking.

\section{INTRODUCTION}

Ultra-high-performance, fibre-reinforced concrete (UHPFRC) (Richard and Cheyrezy, 1995) is a cementitious material with very high binder content and low water/binder ratio. No coarse aggregate is used and fine silica sand with tightly controlled grading is the only aggregate present. A high dosage of superplasticising additive is used and fibre reinforcement is provided by short straight steel fibres. The resulting concrete has very high compressive strength of up to $200 \mathrm{MPa}$ and flexural strength of 20-40 MPa. The corresponding values for normal strength concrete are 30-50 MPa and 3-5 MPa, respectively. In contrast to more conventional concrete, which is brittle and has a very low energy absorption capacity (Banthia et al., 2004), UHPFRC has improved ductility with a fracture energy of $20000-40000 \mathrm{~J} / \mathrm{m}^{2}$.

These properties give UHPFRC the potential to be used to resist explosion and impact. Normal strength concrete would have a tendency to spall or create shrapnel under this type of loading (Nash et al., 1995). Ngo et al. (2007) and Rebentrost and Wight (2008) conducted explosion tests on UHPFRC and normal strength concrete. At a distance of $40 \mathrm{~m}$ from an explosive charge equivalent to $6 \mathrm{t}$ trinitrotoluene (TNT), they found that a $100 \mathrm{~mm}$ thick normal strength concrete panel was severely damaged with wide cracks and spalling on both the front and rear faces, whereas a UHPFRC panel of the same thickness suffered only minor damage.

A research project has recently been carried out at the Universities of Liverpool and Sheffield to investigate the properties of UHPFRC under impact and explosion loading for anti-terrorism applications. The project has included various static and dynamic laboratory testing of UHPFRC as well as finite-element modelling (Barnett, 2008; Barnett et al., 2007). This briefing paper describes blast tests of some full-scale UHPFRC panels that were carried out in conjunction with VSL Australia and the Centre for Protection of National Infrastructure in 2008.

\section{EXPERIMENTAL TESTING}

Four UHPFRC panels measuring $3.5 \mathrm{~m}$ high by $1.3 \mathrm{~m}$ wide by $100 \mathrm{~mm}$ thick were manufactured and tested under explosion loading. The panels were manufactured by VSL Australia and shipped to the UK for testing. The panels were positioned at an appropriate stand-off distance from an explosive charge equivalent to $100 \mathrm{~kg}$ TNT. The stand-off distance was chosen to ensure failure of the panel, based on the results of single-degreeof-freedom models and predictive finite-element modelling using the Autodyn software (supplied by Ansys, Horsham Sussex, UK). Table 1 shows the details of the panels and their stand-off distances from the explosive charge. Panels A and B were replicate panels which contained conventional steel reinforcement in addition to $2 \%$ by volume of $13 \mathrm{~mm}$ long straight steel fibres and were positioned at different stand-off distances ( 9 and $7 \mathrm{~m}$, respectively). Panels $\mathrm{C}$ and D contained no steel reinforcing bars and differed only in their fibre content, with panel D containing a mixture of two different types of fibre. These two panels were tested at the same stand-off distance of $12 \mathrm{~m}$.

The panels were simply supported at the top and bottom. Reflected pressure resulting from the blast wave was recorded at $12 \mathrm{~m}$ distance from the charge. Deflection was recorded using laser gauges on the rear face of the panel and a simple broomstick device which enabled measurement of the peak deflection and permanent deflection of the mid-span of the panel.

\section{RESULTS AND DISCUSSION}

Table 1 includes the maximum and permanent deflections of the four panels as measured by the broomstick gauge. The panels with steel reinforcing bars (A and B) both deflected and then partially recovered. They survived the relatively close explosions with only minor cracks (Figure 1(a)). The panels with no steel reinforcing bars (C and D) deflected to a maximum value and remained in that position. Both panels cracked horizontally 


\begin{tabular}{|c|c|c|c|c|c|c|}
\hline \multirow[b]{2}{*}{ Panel } & \multicolumn{2}{|c|}{ Fibres: $\%$ by volume } & \multirow[b]{2}{*}{ Reinforcing steel } & \multirow[b]{2}{*}{ Stand-off: m } & \multirow{2}{*}{$\begin{array}{c}\text { Maximum } \\
\text { deflection: } \mathrm{mm}\end{array}$} & \multirow{2}{*}{$\begin{array}{c}\text { Permanent } \\
\text { deflection: } \mathrm{mm}\end{array}$} \\
\hline & $13 \mathrm{~mm}$ long & $25 \mathrm{~mm}$ long & & & & \\
\hline A & 2 & - & yes & 9 & 110 & 20 \\
\hline B & 2 & - & yes & 7 & 210 & 50 \\
\hline C & 2 & - & no & 12 & 180 & 180 \\
\hline $\mathrm{D}$ & 2 & 2 & no & 12 & 90 & 90 \\
\hline
\end{tabular}

Table I. Details of UHPFRC test panels

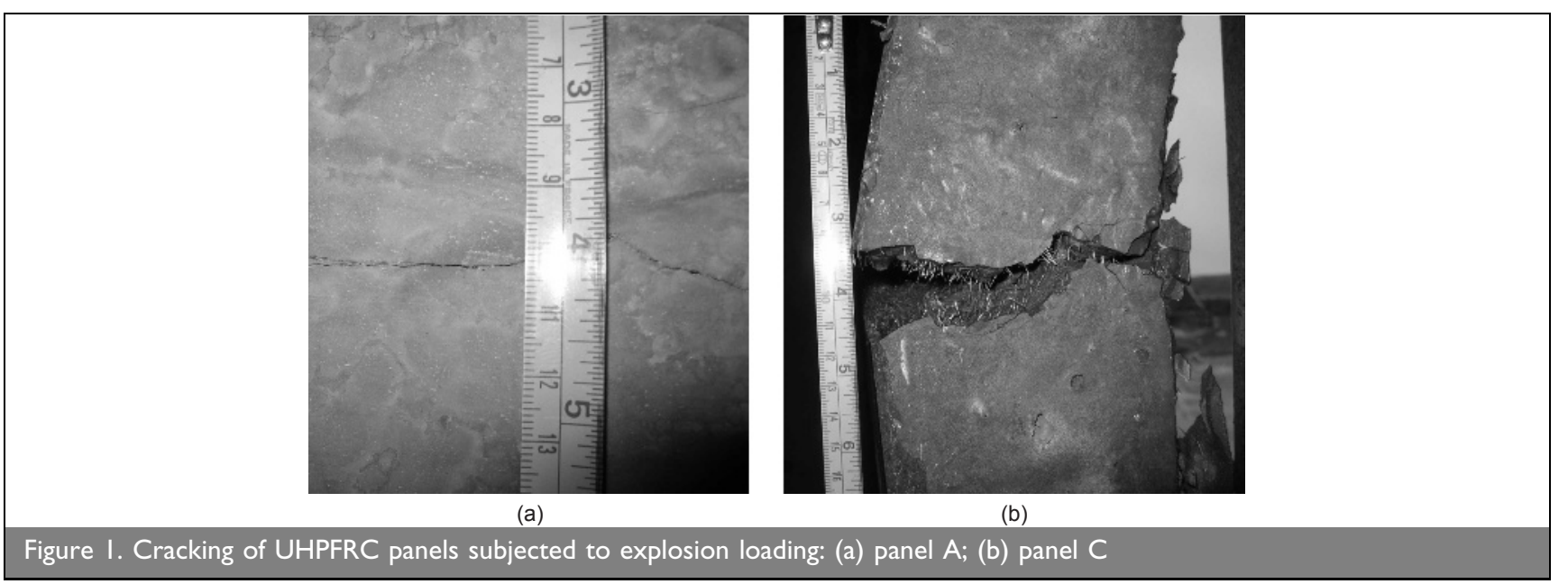

across their full width. Figure 1(b) shows the cracking of panel $\mathrm{C}$, the weakest of the four panels. Despite this severe crack, the panel remained standing after the test (Figure 2). Panel D, which contained a total of $4 \%$ by volume of two types of fibres had a final deflection which was half that of panel C $(90 \mathrm{~mm}$ in comparison with $180 \mathrm{~mm}$ for panel C). For normal strength concrete, blast loading can cause spalling from the rear face and the creation of shrapnel, which can cause severe injury to people behind the panel. In these tests, there was no evidence of these effects.

\section{CONCLUSIONS}

Ultra-high-performance, fibre-reinforced concrete has been shown to have properties which make it suitable for resisting

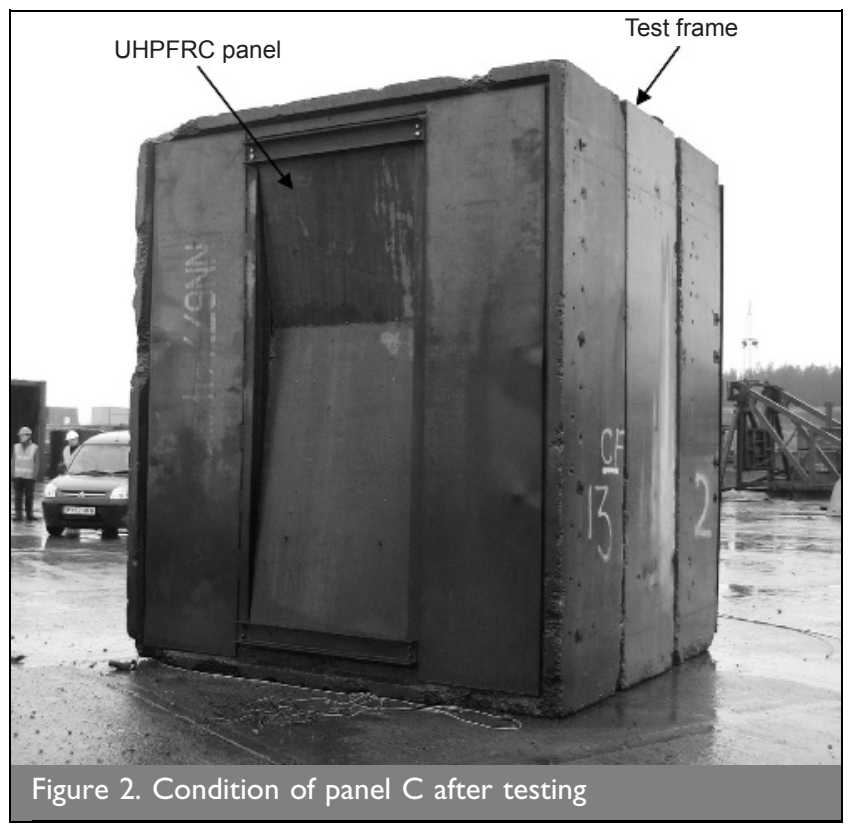

explosions and could therefore be utilised to protect people and buildings from the effects of terrorism. The exact details of the panel (e.g., use of higher fibre contents, secondary reinforcing steel) clearly have a significant effect on its performance and the design of the panel could be tailored to suit the threat that the panel is required to withstand. It is hoped that further research will be carried out to develop UHPFRC for specific applications in the protection of civilian and/or military personnel and buildings.

\section{ACKNOWLEDGEMENTS}

The authors acknowledge the significant contributions of Centre for Protection of National Infrastructure, VSL Australia and Bekaert Limited. This work was carried out as part of a research project funded by the Engineering and Physical Sciences Research Council's Think-Crime 4 initiative. We are also grateful to the staff of Advantica Technology, RAF Spadeadam.

\section{REFERENCES}

Banthia N, Bindiganavile V and Mindess S (2004) Impact and blast protection with fiber reinforced concrete. Proceedings of the 6th RILEM Symposium on Fibre-reinforced Concretes (FRC) (Di Prisco M, Felicetti R and Plizzari GA (eds)). RILEM Publications, Varenna, Italy, pp. 31-44.

Barnett SJ (2008) Development of advanced concrete materials for anti-terrorism applications. The Structural Engineer 89(19): 28-29.

Barnett SJ, Millard SG, Soutsos MN, Schleyer GK, Tyas A and Le TT (2007) Ultra high performance fibre reinforced concrete for explosion resistant structures. Proceedings of Concrete Platform (Russell MI and Basheer PAM (eds)). Queen's University of Belfast, Belfast, UK, pp. 565-573.

Nash PT, Vallabhan CVG and Knight TC (1995) Spall damage to concrete walls from close-in cased and uncased explosions in air. ACI Structural Journal 92(6): 680-688. 
Ngo T, Mendis P and Krauthammer T (2007) Behavior of ultrahigh-strength prestressed concrete panels subjected to blast loading. Journal of Structural Engineering 133(11): 1582-1590.

Rebentrost M and Wight G (2008) Behaviour and resistance of ultra high performance concrete to blast effects. Proceedings of the 2nd International Symposium on Ultra High

Performance Concrete (Fehling E, Schmidt M and Stürwald S (eds)). Kassel University Press, Kassel, Germany, pp. 735-742. Richard P and Cheyrezy M (1995) Composition of reactive powder concretes. Cement and Concrete Research 25(7): 1501-1511.

\section{What do you think?}

To discuss this briefing, please email up to 500 words to the editor at journals@ice.org.uk. Your contribution will be forwarded to the author(s) for a reply and, if considered appropriate by the editorial panel, will be published as discussion in a future issue of the journal.

Proceedings journals rely entirely on contributions sent in by civil engineering professionals, academics and students. Papers should be 2000-5000 words long (briefing papers should be 1000-2000 words long), with adequate illustrations and references. You can submit your paper online via www.icevirtuallibrary.com/content/journals, where you will also find detailed author guidelines. 